\title{
PENERAPAN METODE SIMPLIFY RETUR DALAM SISTEM INFORMASI KEUANGAN BERBASIS WEB
}

\author{
Yanti $^{1}$ \\ Untung Rahardja ${ }^{2}$ \\ Tri Purwaningsih ${ }^{3}$ \\ e-mail :yanti@yahoo.com,untung.rahardja@faculty.raharja.ac.id, \\ tripurwaningsih@si.raharja.ac.id
}

Diterima :21 Juni 2010/Disetujui : 28 Agustus 2010

\begin{abstract}
Seiring dengan kemajuan teknologi informasi yang semakin pesat mendorong adanya perkembangan teknologi jaringan. Pemanfaatan sistem informasi merupakan suatu keharusan untuk mendukung mutu pelayanan di segala bidang, begitu juga dalam hal keuangan baik didalam suatu organisasi maupun perusahaan. Dimana banyak sekali transaksi keuangan yang dilakukan oleh bagian tersebut, sehingga dibutuhkan suatu system yang handal. Namun meskipun telah menggunakan sistem informasi, seringkali masih terjadi suatu kesalahan yang tak terduga ataupun transaksi yang batal. Sehingga memerlukan suatu sistem yang dapat mengakomodir pengembalian-pengembalian yang terjadi agar laporan keuangan dapat sesuai dengan yang seharusnya. Selain itu seringkali pembuatan retur dilakukan secara terpisah sehingga menyulitkan untuk menggabungkan segala transaksi yang terjadi, baik transaksi bernilai plus ataupun minus (retur). Dengan demikian diperlukan adanya penyederhanaan didalam suatu system informasi untuk menghasilkan suatu system transaksi yang handal dan efisien. Dalam artikel ini, di identifikasikan masalah yang dihadapi dari suatu proses transaksi, keuntungan dari penggunaan simplify retur, serta implementasinya, yang ditampilkan dalam listing program yang ditulis menggunakan script ASP. Simplify Retur merupakan suatu solusi yang sangat membantu kebutuhan user dalam menghasilkan suatu laporan transaksi keuangan.
\end{abstract}

Kata kunci: Retur, Sistem Informasi, Simplify Retur

1. Dosen Jurusan Komputerisasi Akuntansi, Universitas Bina Nusantara

J1. K.H. Syahdan No. 9, Palmerah, Jakarta Barat, 11480

2. Dosen Jurusan Sistem Informasi, STMIK Raharja

J1. jend Sudirman No. 40 Modern Cikokol-Tangerang Telp. 5529692

3. Mahasiswa Sistem Informasi, STMIK Raharja

Jl. jend Sudirman No. 40 Modern Cikokol-Tangerang Telp. 5529692 


\section{PENDAHULUAN}

Perkembangan teknologi yang terus meningkat dengan cepat, mampu memberikan pengaruh besar di begitu banyak aspek kehidupan, baik itu disekitar tempat tinggal, perguruan tinggi, dunia bisnis, tempat kerja, dan lain-lain. Kemajuan teknologi sendiri didalamnya mengandung beragam kemudahan yang ditawarkan, dan apabila hal ini dapat dimanfaatkan dengan baik maka otomatis akan dapat meningkatkan kinerja bagi penggunanya. Teknologi yang berkembang pesat, mempunyai dampak yang paling dominan terhadap perubahan lingkungan bisnis maupun di kehidupan sehari-hari. Selain itu penggunaan database pada bagian keuangan dalam suatu perusahaan dan organisasipun semakin banyak terlebih dengan adanya sistem jaringan.

Perusahaan dan organisasipun membutuhkan sistem informasi keuangan untuk mengumpulkan dan mengolah data serta menyimpan data transaksi yang dapat di salurkan pada suatu informasi. Sistem transaksi tersebut dapat dilakukan dengan adanya sistem yang terkontrol oleh bagian pelayanannya.

Pemanfaatan sistem keuangan secara garis besar bertujuan untuk memudahkan proses pelaksanaan transaksi. Melalui sistem keuangan, diharapkan proses pelayanan dapat dilaksanakan lebih mudah, cepat, efisien dan efektif. Meningkatnya kecenderungan transaksi yang didukung oleh perkembangan teknologi menyebabkan sistem keuangan menjadi semakin terintegrasi tanpa jeda waktu. Selain itu, inovasi transaksi keuangan semakin dinamis dan beragam dengan kompleksitas yang semakin tinggi. Berbagai perkembangan tersebut selain dapat mengakibatkan sumber-sumber pemicu ketidakstabilan sistem keuangan meningkat dan semakin beragam, juga dapat mengakibatkan semakin sulitnya mengatasi ketidakstabilan

Ketidakstabilan yang terjadi dapat berupa arus transaksi, dimana suatu proses transaksi berlangsung satu arah. Artinya hanya proses input data yang terjadi pada sistem informasi keuangan tersebut. Sehingga apabila terjadi selisih dikarenakan transaksi yang batal, harus dilakukan proses retur yang berbelit-belit.

\section{PERMASALAHAN}

Adanya sistem informasi yang canggih disegala bidang, termasuk didalamnya dalam hal keuangan, memberikan banyak kemudahan bagi para penggunanya (customer). Namun diantara keunggulan itu sistem informasi juga memungkinkan suatu sistem yang kompleks, karena banyaknya informasi yang harus diakomodir serta banyaknya user yang melakukan proses input seringkali mengakibatkan terjadinya kesalahan dalam penginputan data transaksinya. Sehingga laporan 
keuangan yang ada menjadi tidak sesuai dengan yang diinginkan karena data yang kotor. Berikut ini di sampaikan tampilan sumber data transaksinya :

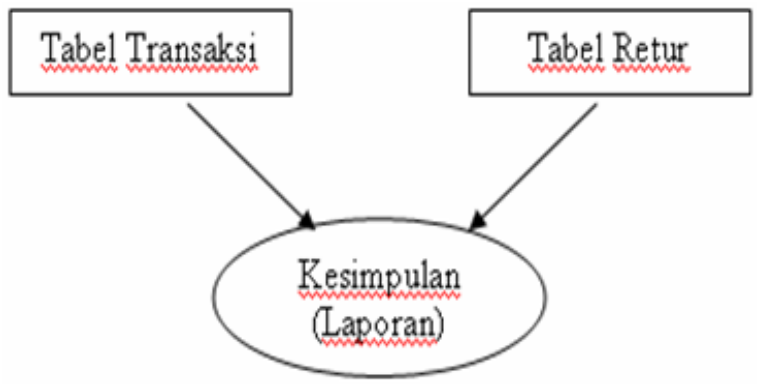

Gambar 1. struktur database sistem informasi keuangan

Dari gambar tersebut, dapat dilihat bahwa untuk menghasilkan suatu laporan keuangan maka harus dilakukan penggabungan antara tabel transaksi dan tabel retur. Penggabungan dilakukan agar didapat suatu kesimpulan atau laporan berdasarkan data yang diinput dan diretur. Jika ada beberapa tabel di dalam suatu sistem transaksi, kemudian sistem tersebut mengalami kesalahan akan terjadi pengurangan pada tabel retur.

Berdasarkan uraian di atas, maka permasalahan yang akan dikemukakan adalah bagaimana membuat retur di dalam suatu sistem database yang menjadi dasar proses penggabungan antara tabel transaksi dengan tabel retur sehingga akan menghasilkan data yang sinkron, serta metode yang dapat mempermudah suatu proses retur.

\section{CRITICAL REVIEW}

Banyak penelitian yang sebelumnya dilakukan mengenai struktur database untuk suatu sistem informasi. Dalam upaya mengembangkan struktur database perlu dilakukan studi pustaka sebagai salah satu dari penerapan metode penelitian yang akan dilakukan. Diantaranya adalah mengidentifikasikan kesenjangan (identify gaps), menghindari pembuatan ulang (reinventing the wheel), mengidentifikasikan metode yang pernah dilakukan, meneruskan penelitian sebelumnya, serta mengetahui orang lain yang spesialisasi dan area penelitiannya sama dibidang ini. Beberapa Critical Review tersebut adalah sebagai berikut :

1. Penelitian yang dilakukan oleh Pierangela Samarati (Computer Science Technology) \& Sushil Jajodia (Center for Secure Information System) berjudul Data Security. Perkembangan teknologi komputer yang semakin cepat, canggih dan 
berkemampuan tinggi meliputi: kapasitas memori yang semakin besar, proses data yang semakin cepat dan fungsi yang sangat majemuk (multi fungsi) serta semakin mudahnya komputer dioperasikan melalui beberapa paket program, berdampak pula pada proses pengamanan data. Dari hasil referensi-referensi dari beberapa penelitian dan pustaka, terdapat beberapa langkah yang dapat dilakukan sebagai wujud dari proses pengamanan data, diantaranya, yaitu: Identifikasi dan Otentifikasi, Akses Kontrol, Audit, Encryption. Langkah-langkah tersebut diambil untuk memelihara Confidentiality / Privacy, Integritas dan Availability (Ketersediaan) dari data tersebut. Implementasi mengenai penelitian tersebut dapat dilihat dalam beberapa contoh proses pengamanan data untuk suatu aplikasi. Penelitian tersebut juga menginformasikan mengenai pengenalan berbagai macam alat-alat pengamanan data. Sesuai dengan kemajuan teknologi informasi saat ini, penelitian tersebut seharusnya juga dapat mengatur bagaimana cara pengamanan.

2. Penelitian ini dilakukan oleh Untung Rahardja, Muhamad Yusup, LilikAgustin dari perguruan tinggi raharja indonesia,berjudul "Pengontrolan Mutu Sistem Informasi dengan Metode Database Health Monitoring". Pada penelitian ini menjelaskan mengenai Database Health Monitoring (DHM), yang menggabungkan metode Database Self Monitoring (DSM) dan Server Health Indicator (SHI). DHM didefinisikan sebagai dashboard system yang menampilkan indikator sistem informasi dan indikator kapasitas penyimpanan data secara bersamaan, dengan DHM dapat mengantisipasi segala kemungkinan data anomaly dengan menggunakan teknik pengendalian mandiri untuk memperbaiki mutu sistem informasi dan pengendalian mandiri kapasitas penyimpanan. Perkembangan teknologi informasi dan komputer yang pesat telah memberikan dukungan yang besar pada kegiatan organisasi ataupun perusahaan, teknologi informasi dan komputer tersebut pada umumnya digunakan untuk mendukung pengolahan data transaksional harian organisasi ataupun perusahaan untuk dapat menghasilkan informasi yang cepat, tepat, akurat dan relevan. Namun sebuah sistem informasi, dimana sistem tersebut masih banyak mendapatkan keluhan dari berbagai pihak untuk dilakukan perbaikan pada sebuah sistem informasi. Hal ini pula yang dapat menyebabkan timbulnya permasalahan pada sistem informasi, dimana sistem informasi yang baik mempunyai sebuah indikator, yang berguna untuk mendeteksi kemungkinan-kemungkinan kesalahan yang dapat terjadi di dalam jalannya sistem informasi, inilah permasalahan dari sebuah sistem informasi dimana menghambat kinerja sebuah sistem dan kualitas mutu dari sistem informasi dianggap masih rendah. Untuk mencegah agar hal-hal yang tidak diinginkan dapat terjadi di dalam sebuah sistem informasi dan berjalan sebagaimana mestinya, salah satu cara yang biasa dilakukan yaitu dengan menggunakan dashboard sebagai sebuah indikator di dalam sistem informasi. 
3. Penelitian ini dilakukan oleh Yin-Fu Huang dan HER JYH-CHEN dari Universitas Nasional Sains dan Teknologi Yunlin Taiwan, berjudul "Fragment Allocation in Distributed Database Design". Pada penelitian ini menjelaskan mengenai Wild Area Network (WAN), fragmen alokasi adalah isu utama dalam distribusi database desain karena kekhawatiran kinerja keseluruhan didistribusikan pada system database. Disini system yang diusulkan sederhana dan modelnya yang komprehensif mencerminkan aktivitas transaksi yang didistribusikan dalam database. Berdasarkan model dan informasi transaksi, dua bentuk algoritma dikembangkan untuk mendapatkan alokasi yang optimal seperti total biaya komunikasi yang sebisa mungkin diminimalkan. Hasilnya menunjukkan bahwa alokasi fragmentasi ditemukan dengan menggunakan algoritma yang tepat akan menjadi lebih optimal. Beberapa penelitian juga dilakukan untuk memastikan bahwa biaya rumus dapat benar-benar mencerminkan biaya komunikasi didunia nyata.

4. Penelitian ini dilakukan oleh Dias Satria,berjudul "Lumpuhnya fungsi retur perbankan bumerang kemajuan teknologi dan globalisasi keuangan”. penelitian ini membahas mengenai fungsi retur perbankan dari transaksi yang disebabkan oleh beberapa permasalahan yang kompleks. Di dalam globalisasi keuangan dan kemajuan teknologi dilakukan sebatas survey yang diharapkan dapat menjadi jembatan bagi kebutuhan supervisi dan regulasi perbankan. Permasalahan yang menjadi pemicu tingginya globalisasi keuangan secara tidak langsung mempengaruhi aktifitas bisnis perbankan. Namun dapat diharapkan bagi stabilitas keuangan dan pembangunan transaksi ekonomi, maka relevan perbaikan fungsi retur akan berpengaruh dengan baik.

5. Penelitian ini dilakukan oleh Rachel Lyne, Francois Guillier dari Department of Genetics, University of Cambridge berjudul "FlyMine: an integrated database for Drosophila and Anophelesgenomics". Penelitian ini membahas mengenai Database yang diintegrasi dan memanfaatkan keragaman data biologis saat ini. Penelitian ini bermula dari tujuan FlyMine yang termasuk fungsional data untuk berbagai organisme, dengan dimuat berbagai data dan diringkas dalam Tabel untuk data yang menggambarkan database yang digunakan. Sebagai salah satu titik awal menyajikan prinsip tipe data yang menyediakan informasi latar belakang tentang sumber databasenya. Dengan penelitian ini telah dapat membuat sebuah log-in, user untuk dapat menyimpan transaksi, serta query yang dapat diubah.

6. Penelitian ini dilakukan oleh I Nyoman Sutapa, Fakultas Teknologi Industri, Jurusan Teknik Industri, Universitas Kristen Petra berjudul "Komitmen dan Kapabilitas untuk meningkatkan Kinerja Reverse Logistic" penelitian ini membahas mengenai Reverse logistics (RL) adalah proses perencanaan, implementasi, dan 
pengendalian secara efisien dan efektif yang meliputi semua aktivitas logistic retur. Komitmen perusahaan mengorganisasikan dan mendayagunakan teknologi logistik terbukti memengaruhi secara signifikan kinerja RL. Kapabilitas inovasi yang berperan penting disini adalah kemampuan melakukan kustomisasi pemanfaatan sarana pertukaran data/informasi antara perusahaan dan mitra rantai distribusi.

7. Penelitian yang dilakukan oleh Stephane Gançarski, Claudia León, Hubert Naacke, Marta Rukoz and Pablo Santini yang berjudul "Integrity Constraint Checking in Distributed Nested Transactions over a Database Cluster" adalah sebuah solusi untuk memeriksa integritas dan kendala global dalam berhubungan multi database sistem. Penelitian ini juga menyajikan hasil eksperimental yang diperoleh atas solusi PC cluster dengan Oracle9i DBMS. Tujuan adalah melakukan eksperimentasi untuk mengukur waktu yang dihabiskan dalam memeriksa kendala global dalam sistem yang terdistribusi. Alhasil menunjukkan bahwa overhead berkurang hingga 50\% dibandingkan dengan pemeriksaan integritas yang terpusat. Studi menunjukkan bahwa sistem berkemungkinan besar melanggar referential integrity dan global conjunctive constraints. Namun dengan cara distributed nested transactions, dengan adanya eksekusi dan parallelism, integritas dapat lebih terjamin.

8. Penelitian ini dilakukan oleh Allison L. Powell James C.dkk, Perancis Departemen Ilmu Komputer Universitas Virginia, berjudul berjudul "The Impact of Database Selection on Distributed Searching”. Penelitian ini menjelaskan bahwa distributed searching terdiri dari 3 bagian yaitu database selection, query processing, dan results merging. Cukup beberapa database yang dijadikan database seleksi (tidak semuanya) dan performa akan meningkat cukup signifikan. Bila seleksi database dilakukan dengan baik, pencarian secara distributed akan berkinerja lebih baik dibandingkan pencarian secara sentralisasi. Pencarian database juga ditambahkan proses seleksi dan ranking sehingga secara potensial meningkatkan efektifitas pencarian data.

9. Penelitian yang dilakukan oleh Hamidah Ibrahim, "Deriving Global Integritas Dan Local Rules For Distributed Database”. Fakultas Ilmu Komputer dan Teknologi Informasi Universitas Putra Malaysia, 43400 UPM Serdang. Ibrahim mengatakan bahwa tujuan terpenting didalam database sistem adalah menjamin konsistensi data, yang berarti bahwa data yang terdapat dalam database harus baik dan akurat. Didalam pelaksanaannya untuk menjaga konsistensi perubahan data sangat sulit, khususnya untuk didistribusikan dalam database. Dalam tulisan ini, menjelaskan sebuah algoritma penegakan aturan berdasarkan mekanisme untuk didistribusikan database yang bertujuan meminimalisir jumlah data yang harus 
ditransfer atau diakses diseluruh jaringan yang menjaga konsistensi dari database di satu situs, yaitu di situs mana pembaruan perlu dilakukan. Teknik ini disebut sebagai tes integritas generasi, yang berasal dari lokal dan global integritas, dan aturan yang telah efektif dapat mengurangi biaya kendala dalam memeriksa suatu data yang telah didistribusikan dalam lingkungan. Didalam penelitian ini telah berhasil menghasilkan sebuah sistem sentralistik yang besar dengan tingkat kehandalan yang tinggi untuk integritas data.

10. Penelitian ini dilakukan oleh John Y.Campbell and Luis M.Viceiran.berjudul “ The Term Strukture of the Risk-Retur Tradeoff'. Penelitian ini membahas mengenai penelitian terbaru dibidang keuangan empiris telah didokumentasikan yang diharapkan pengembalian kelebihan obligasi dan saham. Tingkat suku bunga riil dan pergeseran resiko atas waktu dengan cara ditebak. Selain itu pergeseran ini cenderung terus berlanjut periode waktu yang panjang. Namun sederhana untuk diterapkan dalam praktek dan kami mengeksploiasi implikasinya terhadap alokasi asset. Perubahan peluang investasi dapat mengubah resiko-retur tradeoff obligasi, saham, dan uang tunai di horison investasi sehingga menciptakan suatu istilah struktur resiko-retur tradeoff, yang menggambarkan pendekatan, kami menggunakan data dan saham . telah mengeksplorasi investor jangka panjang yang empiris. Bukti prediktabilitas pengembalian aset. Hal itu menunjukkan bahwa kembali peramalanvariabel seperti hasil dividen, suku bunga, dan menyebar haasil.dengan menggunakan model empiris untuk peluang investasi berbeda dengan kesederhanaan menarik buy dan terus,ratavarians, portofolio strategi dan untuk membandingkan dua pendekatan yang lebih sistematis.

11. Penelitian ini dilakukan oleh John C. Bogle, Founder and Senior Chairman The Vanguard Group dari Institute for Private Investors Spring Forum May 21, 1998.berjudul "The Four Dimensions of Investment Retur".penelitian ini membahas mengenai Tujuan dari investasi jangka panjang adalah akumulasi kekayaan, yang pada gilirannya tergantung pada mencapai tingkat pengembalian investasi yang optimal. Dan pengembalian investasi, menurut saya, memiliki empat dimensi. Namun, tampaknya bagi saya bahwa ekuitas harus tetap pilihan investasi bagi investor jangka panjang. Mereka yang percaya bahwa pasar yang luar biasa momentum dan arus kas akan terus, dan menerima tesis bahwa kita memang di era baru pertumbuhan global, akan terus baris dalam alokasi ekuitas mereka. Secara bertahap menggantikan investasi saham seperti yang disebut, dalam nilai dan relatif tidak likuid aset seperti modal ventura (perusahaan yang muncul), modal swasta (lebih berpengalaman perusahaan), dan aset keras seperti real estate dan energi. Sulit untuk mengukur sejauh mana risiko telah berkurang, karena tidak adanya arus harga untuk investasi likuid membuat langkah-langkah sulit untuk menghitung volatilitas. Namun, 
sejauh ini setidaknya, hal itu tidak muncul bahwa pendekatan-pendekatan alternatif telah berhasil dalam meningkatkan kembali.

Dari Critical Review yang ada, telah melakukan penelitian mengenai system Retur, disamping itu juga telah ada pembahasan mengenai Distributed Database. Untuk penelitian terkait dengan penerapan retur, belum banyak dilakukan oleh para peneliti diatas. Ada juga peneliti yang khusus terkait keamanan database. Namun demikian dapat disimpulkan pula secara keseluruhan bahwa secara khusus belum ada pembahasan seputar masalah Simplifed Retur ataupun Penerapan Retur.

\section{PEMECAHAN MASALAH}

Untuk mengatasi permasalahan seperti yang telah dijelaskan di atas, dapat dilakukan melalui penerapan retur. Retur merupakan suatu kegiatan yang dilakukan untuk mengembalikan suatu kegiatan transaksi.

Penyebab terjadinya retur:

1. Terjadinya kesalahan dalam penginputan data.

2. Transaksi yang batal

Retur dalam suatu sistem informasi dapat berupa:

1. Transaksi yang dilakukan oleh bagian terkaitan agar jumlah yang tidak sesuai tidak masuk ke dalam laporan keuangan.

2. Transaksi bernilai negatif(-), untuk mengurangi jumlah yang telah disetorkan sebelumnya.

Didalam sebuah sistem informasi keuangan yang berbasis web, dimana semua data yang ada tersimpan didalam suatu database. Maka segala transaksi yang dilakukan juga datanya masuk dan tersimpan didalam database. Namun bagaimana agar suatu transaksi retur ini dapat berjalan semaksimal mungkin. Kebanyakan transaksi retur dilakukan dengan memanfaatkan pembuatan tabel baru yang difungsikan khusus untuk transaksi tersebut, Contoh : tabel retur. Sehingga didalam database terdapat dua tabel untuk transaksi yaitu tabel transaksi dan tabel retur. Penggunaan 2 (dua) tabel ini menjadi kurang efektif karena untuk itu berarti harus mengcompare dua tabel tersebut barulah dapat dihasilkan suatu laporan yang sesuai. Hal ini mengakibatkan sistem database nya menjadi lebih kompleks.

Untuk itu dikembangkanlah suatu metode simplified retur untuk dapat menyederhanakan struktur database dalam suatu sistem informasi keuangan berbasis web. Simplified retur merupakan suatu metode yang digunakan untuk retur (penngembalian) perlu membuat tabel baru (retur). Dengan metode ini maka semua transaksi retur yang dilakukan adalah bernilai minus. Transaksi retur yang terjadi 
juga masuk kedalam tabel yang sama bersama transaksi lain yaitu kedalam tabel transaksi.

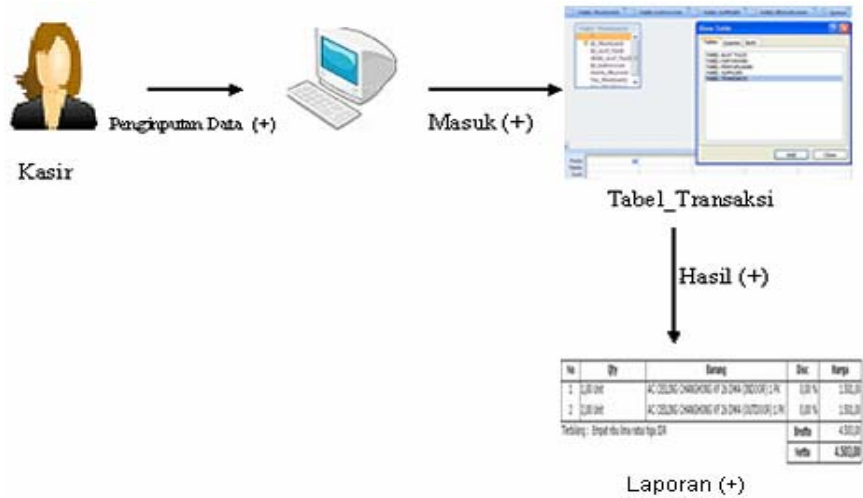

Gambar 2. Struktur Penginputan Penerimaan Transaksi

Dari gambar diatas dapat diketahui bagaimana proses suatu transaksi terjadi. Transaksi diatas merupakan transaksi yang dilakukan oleh bagian front office yang dalam hal ini merupakan kasir, dimana setiap transaksi yang terjadi selalu bernilai positif(+). Begitu pula yang masuk ke dalam database nya yaitu hanya yang bernilai positif(+).

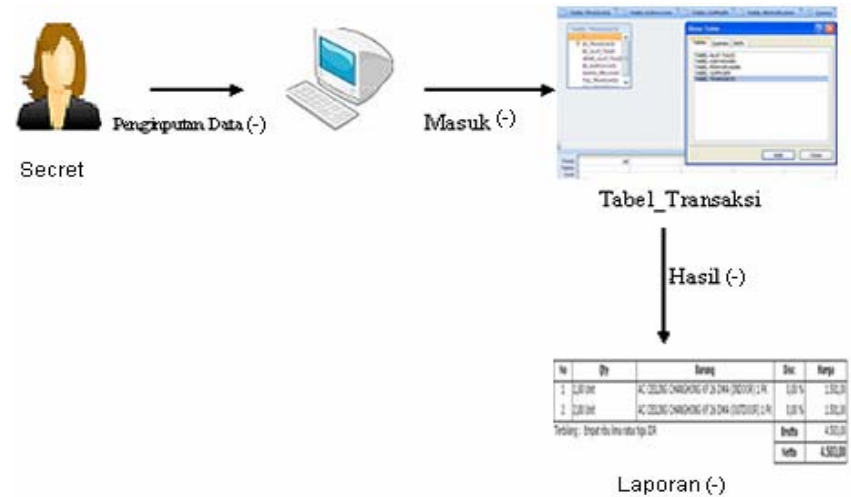

Gambar 3. Struktur Penginputan Retur

Dari gambar diatas dapat diketahui bagaimana proses transaksi retur yang dalam hal ini dijalankan oleh bagian diatas kasir yang disebut secret chamber. Jika pada proses transaksi sebelumnya semua transaksi bernilai positif $(+)$ maka sebaliknya pada transaksi retur, semua transaksi yang dijalankan selalu bernilai negatif(-). 
Kelebihan dari penggunaan metode simplified retur adalah dapat menyeimbangkan transaksi yang terjadi. Dimana dalam suatu transaksi keuangan seringkali terjadi kesalahan yang tak terduga. Sehingga diperlukan adanya suatu fasilitas retur untuk dapat mengatasi hal tersebut. Selain itu dari segi databasenya akan lebih mudah untuk mendefinisikan jumlah untuk laporan keuangan karena tidak perlu lagi dilakukan comparisasi atau pengurangan antara tabel transaksi dan tabel retur.

\section{IMPLEMENTASI}

Metode Simplify Retur telah diimplementasikan pada Perguruan Tinggi Raharja, yaitu pada sistem informasi keuangan yang dikenal dengan GO IAC. Green Orchestra (GO) merupakan Green Orchestra yang mengilustrasikan Divisi Keuangan Perguruan Tinggi Raharja yang tidak beraktivitas manunggal, tapi memetik instrumen musiknya (menjalankan aktivitas sehari-hari) yang berirama dan harmonis (kerjasama yang baik dengan divisi lain), sesuai dengan komando dirijen (Pimpinan Perguruan Tinggi Raharja).

GO sudah dikembangkan menjadi beberapa versi yang merupakan kelanjutan dari versi sebelumnya. GO IAC merupakan GO ver.3. GO IAC dibuat untuk memenuhi kegiatan transaksi keuangan yang ada di bagian layanan keuangan mahasiswa (LKM). Sehingga seluruh transaksi keuangan di jalankan melalui sistem informasi keuangan berbasis web yang tentunya bersifat online. Transaksi yang dapat dilakukan pada GO IAC adalah transaksi pembayaran registrasi, Sks, serta pembayaran-pembayaran lainya. Salah satu keunggulan dari GO IAC adalah setiap transaksi yang dilakukan akan secara langsung tercapture dilaporan keuangan baik harian, bulanan, dan tahunan.

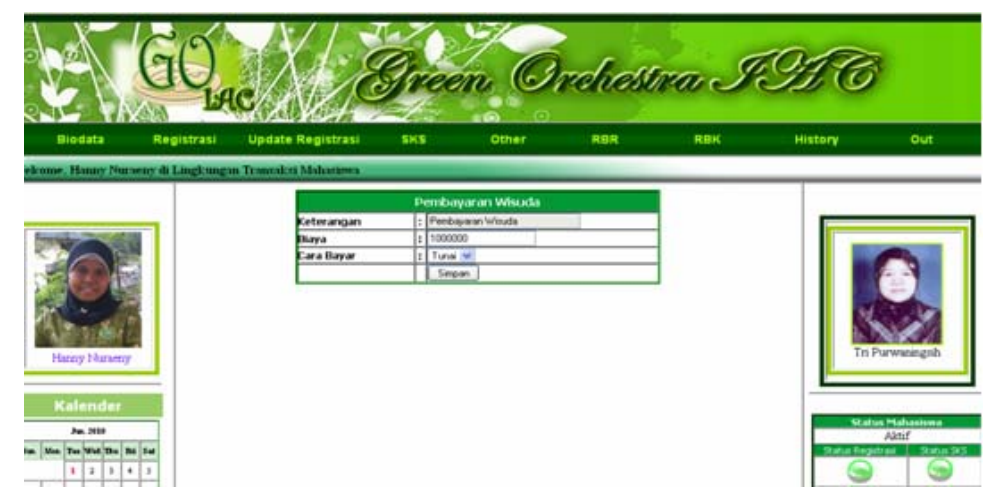

Gamabar 4. Transaksi Mahasiswa 
Gambar di atas merupakan tampilan form untuk transaksi yang ada di panel kasir. Pada form tersebut bisa dilihat bahwa nominal yang diinputkan kasir yaitu bernilai positif $(+)$. Setelah diklik simpan,maka secara otomatis datanya akan masuk ke dalam database. Database yang digunakan pada GO IAC menggunakan SQL Server 2005. Di dalam databse tersebut telah ada sebuah tabel untuk mengcapture semua transaksi.

\begin{tabular}{|c|c|c|}
\hline Column Name & - Data Type & Allow Nulls \\
\hline waktes & smalldatetime & $\sqrt{\sigma}$ \\
\hline admin & varchar(5o) & $\sqrt{\sigma}$ \\
\hline ket & varchar(100) & $\sqrt{\sigma}$ \\
\hline NIM & varchar(10) & $\sqrt{\sigma}$ \\
\hline no_kwitansi & bigint & $\sqrt{2}$ \\
\hline biaya & money & $\sqrt{\sim}$ \\
\hline old & varchar(5o) & $\sqrt{\sigma}$ \\
\hline new & varchar(so) & $\sqrt{\sigma}$ \\
\hline cara_bayar & varchar(10) & $\sqrt{\sigma}$ \\
\hline semester & varchar(10) & $\sqrt{\sigma}$ \\
\hline ta & varchar(10) & $\sqrt{\sigma}$ \\
\hline nama & varchar (150) & $\sqrt{2}$ \\
\hline
\end{tabular}

Gambar 5. Struktur Tabel Transaksi

Tabel di atas merupakan tabel transaksi, dimana field-fieldnya adalah waktu, admin, ket, nim, no_kwitansi, biaya, old, new, cara_bayar, semester, ta, nama.

\begin{tabular}{|c|c|c|c|c|c|}
\hline wats & ath & kd & 101 & robutros & biso \\
\hline $5(\sec 0106020$. & Shinst besta & lopat ustabsessi & $x u$ & uts & $x u$ \\
\hline 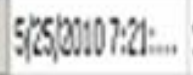 & Shanshess & copatushobassisi & $x u$ & xul & $x$ \\
\hline - E] & Hartiliswery & Perbyegen flodeds & 6115750 & 34742 & 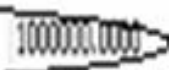 \\
\hline cramenter & Chinghases & Sithount & rematers & vir & vis \\
\hline
\end{tabular}

Gambar 6. Isi Tabel Transaksi

Pada gambar 6 dapat dilihat data yang terinput ke dalam table transaksi yang ada di database. Setelah semua data transaksi masuk ke dalam table transaksi maka akan otomatis juga akan tampil pada laporan keuangan. 


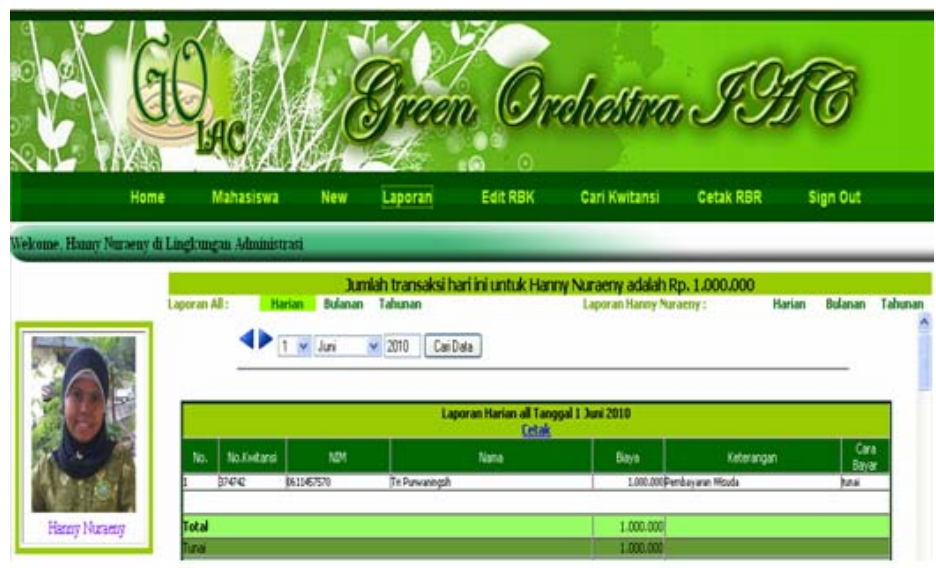

Gambar 7. Tampilan Laporan Keuangan Mahasiswa

Selain panel kasir, pada GO IAC juga terdapat panel Secret Chamber. Pada panel ini terdapat berbagai menu yang dapat dimanfaatkan oleh Secret Chamber diantaranya registrasi, Sks, retur, laporan dll. Jika transaksi yang sebelumnya dimasukkan kasir bermasalah, maka Secret Chamber dapat melakukan retur dengan mengklik menu retur.

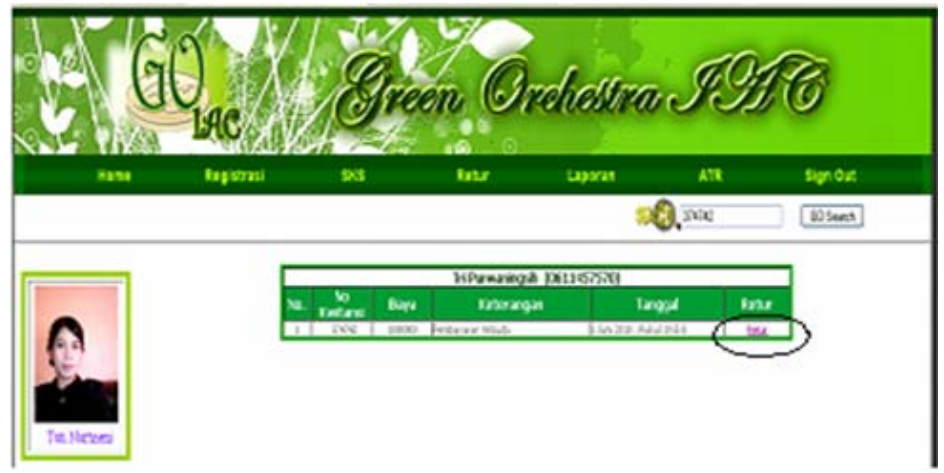

Gambar 8. Tampilan Secret Chamber

Pada gambar di atas dapat dilihat halaman menu retur. Untuk dapat melakukan transaksi retur, Secret Chamber harus memasukkan nomor kwitansi yang ingin dicari untuk di retur setelah muncul tabel informasi, nomor kwitansi yang ingin dicari untuk diretur setelah muncul tabel informasi nomor kwitansi tersebut, klik link retur. 


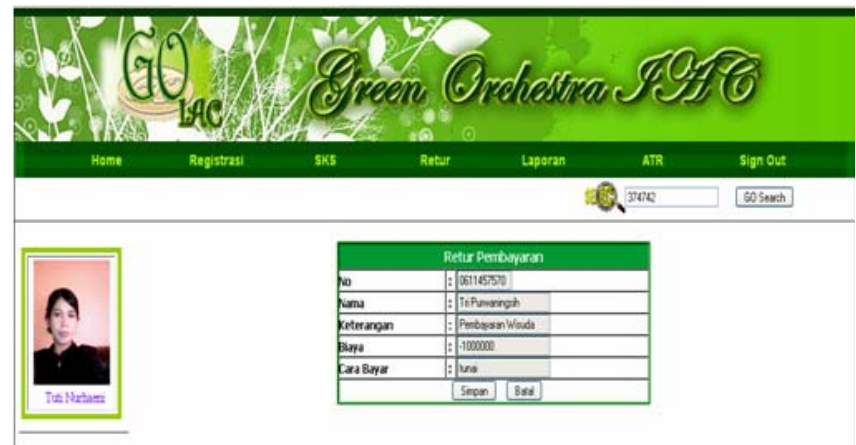

Gambar 9. Tampilan Retur Pembayaran

Setelah link retur diklik maka akan tampil form seperti gambar 9. Dapat dilihat bahwa nominal yang ada pada form retur yaitu bernilai negatif(-). Jika Secret Chamber telah yakin pembayaran tersebut ingin diretur sehingga dapat diklik simpan. Data transaksi retur tersebutpun akan masuk ke dalam database ke dalam tabel yang sama transaksi yang sebelumnya.

\begin{tabular}{|c|c|c|c|c|c|c|}
\hline moktu & adtin & ket & NM & กมMก: & bisyo & m nuitaros \\
\hline ill120107:10.... & "Tuto Nuhroeni & 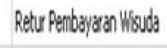 & 0661457530 & Tripuwuringsh & $\cdot 1000000,0000$ & 374743 \\
\hline ill1200107:05... & "Hany Nuseeny & 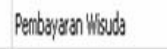 & 061145750 & TinPuwweringsh & 100000,0000 & 374742 \\
\hline VU! & Nu! & NuI & NUI & MUI & NuI & NUI \\
\hline
\end{tabular}

Gambar 10. Tabel Retur

Pada tabel di atas bisa dilihat perbandingan transaksi yang dilakukan kasir bernilai positif(+)dan transaksi yang dilakukan Secret Chamber bernilai negatif(-).

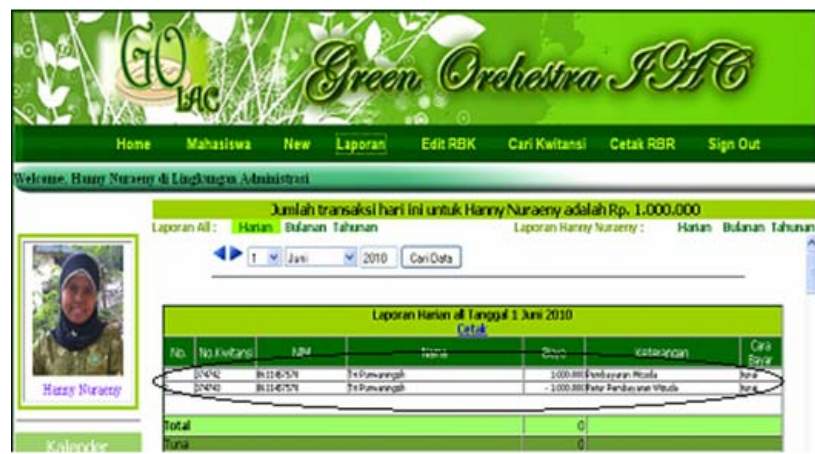

Gambar 11. Tampilan Laporan Keuangan Kasir 
Setelah terjadinya transaksi retur, maka tampilan laporan keuangan berubah menjadi seperti gambar diatas. Dimana transaksi yang dilakukan kasir dan transaksi retur yang dilakukan Secret Chamber masuk ke laporan yang sama.

\section{KESIMPULAN}

Berdasarkan uraian di atas, dapat disimpulkan bahwa Simplify Retur merupakan suatu metode untuk menyederhanakan retur yang kompleks,karena dengan metode ini tidak perlu lagi ada tabel retur. Tabel retur dan tabel transaksi adalah tabel yang sama, hanya saja transaksi kasir bernilai positif $(+)$ sedangkan transaksi retur bernilai negatif (-). Dari sisi tersebut transaksi akan berjalan dengan baik dalam hal pengendalian transaksi keuangan. Dengan metode ini pembuatan laporan keuanganpun menjadi lebih mudah.

\section{DAFTAR PUSTAKA}

1. Samarati Pierangela, Jajodia Sushil. Data Security. Computer Science Laboratory, Center for Secure Information System. SRI International Menlo Park USA, George Mason University Fairfax USA.

2. Rahardja Untung, Yusup Muhamad, Agustin Lilik.Pengontrolan Mutu Sistem Informasi dengan Metode Database Health Monitoring. Perguruan Tinggi Raharja of Indonesion.

3. H.Yin-Fu dan JYH-CHEN HER . 2001. Fragment Allocation in Distributed Database Design. Nasional Yunlin Universitas Sains dan Teknologi Yunlin. Taiwan 640, R.O.C

4. Satria Dias . 2008. Lumpuhnya Fungsi Retur Perbankan Bumerang Kemajuan Teknologi dan Globalisasi Keuangan. Perbankan.

5. Lyne Rachel, Guillier Francois. FlyMine: an integrated database for Drosophila and Anophelesgenomics. Department of Genetics, University of Cambridge .

6. Sutapa I Nyoman. Komitmen dan Kapabilitas untuk meningkatkan Kinerja Reverse Logistic. Fakultas Teknologi Industri, Jurusan Teknik Industri, Universitas Kristen Petra 
7. Gançarski Stephane, León Claudia, Naacke Hubert, Rukoz Marta and Santini Pablo. Integrity Constraint Checking in Distributed Nested Transactions over a Database Cluster.

8. LAllison, James C Powell. The Impact of Database Selection on Distributed Searching. Perancis Departemen Ilmu Komputer Universitas Virginia.

9. Ibrahim Hamidah.Deriving Global Integritas Dan Local Rules For Distributed Database. 2001. Departemen of Computer Science facuty of Computer Science and Information Technology,University Putra Malaysia 43400 UPM Serdang.

10. Y.Campbell John and M.Viceiran Luis. The Term Strukture of the Risk-Retur Tradeoff.

11. C. Bogle John. The Four Dimensions of Investment Retur . 1998. Institute for Private Investors Spring Forum.

12. Hidayati . 2008 . About Green Orchestra (GO) Versi 1. Perguruan Tinggi Raharja. 